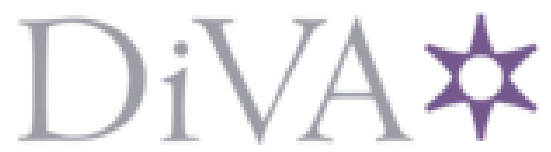

http://www.diva-portal.org

This is the published version of a paper published in Journal of Scandinavian Studies in Criminology and Crime Prevention.

Citation for the original published paper (version of record):

Iqbal, A., Ceccato, V A. (2015)

Does crime in parks affect apartment prices?

Journal of Scandinavian Studies in Criminology and Crime Prevention, 16(1): 97-121

https://doi.org/10.1080/14043858.2015.1009674

Access to the published version may require subscription.

N.B. When citing this work, cite the original published paper.

Permanent link to this version:

http://urn.kb.se/resolve?urn=urn:nbn:se:kth:diva-167789 
Journal of Scandinavian Studies in Criminology and Crime Prevention, 2015

Vol. 16, No. 1, 97-121, http://dx.doi.org/10.1080/14043858.2015.1009674

\title{
Does crime in parks affect apartment prices?
}

\author{
Asifa Iqbal* and Vania Ceccato \\ Housing \& Safety Research Group at CEFIN, School of Architecture and the Built Environment, \\ Royal Institute of Technology, Stockholm, Sweden
}

(Received 29 September 2014; Accepted 12 January 2015)

\begin{abstract}
A park is a desirable feature when people are purchasing a property. Buyers are ready to pay more for properties surrounded by natural amenities, such as a pleasant park. However, if a park is targeted by crime and disorder, then it may have a negative effect on people's appraisal. The aim of this study is to reach a better understanding of how parks and crime rates affect housing prices taking into account residential properties and parks type. Stockholm, the capital of Sweden, is used as the case study. The methodology has two stages. An extensive field work was performed in a selected number of parks to help characterize the parks in Stockholm. This information was gathered with secondary data about parks using Geographic Information System. This pre-assessment was later followed by the analysis of 2008s apartment sales using hedonic modelling to assess the effect of parks alone and in combination with crime rates. Results suggest that the effect of parks on prices vary by park type (increased with, e.g. features of cultural and national interest and decreased with ball games or boating facilities) while an aggregated measure of parks lowers overall apartment prices. More interestingly, findings show that the price of apartments tends to be discounted in areas where parks have relatively high rates of violence and vandalism.
\end{abstract}

Keywords: green areas; offences; GIS; hedonic modelling; spatial lag; spatial error

\section{Introduction}

Parks are often regarded as an urban amenity. They are a source of recreation and aesthetic experiences. Green public spaces serve the common good, and parks help to improve people's health and fitness (e.g. Chiesura, 2004; Hilborn, 2009). However, not all parks are the same, and therefore the effects they may have on individuals and on their surrounding environment are bound to differ. Crime and disorder in green areas may have damaging effects on the quality of life of nearby residents (Groff \& McCord, 2011) and on the housing market (Troy \& Grove, 2008).

This study uses hedonic price modelling to assess the impact of parks and green spaces on apartment prices. Hypothetically, people are willing to pay more for properties close to amenities such as parks (Troy \& Grove, 2008), with the demand for such public amenities reflected in buyers' willingness to pay for these features. Yet, the positive park effect is jeopardized by what happens in the park; for instance, a park that is a magnet for crime and disorder becomes deemed an unsafe place, which in turn may pull housing prices down. The objective of this study is to obtain a better understanding of how parks and crime affect apartment prices.

Stockholm is chosen as the present study's setting for several reasons. In 2012, Sweden's capital was ranked the sixth most livable city in the world by the Economist

\footnotetext{
*Corresponding author. Email: asifa.iqbal@abe.kth.se
} 
Intelligence Unit (Stockholm City, 2012), with the availability of green areas being an important component of what constitutes a livable city. Moreover, compared with other European capitals, Stockholm's inner-city areas generally have more housing and apartment buildings and a systematic geographical distribution of green spaces and parks. Similar to other cities, Stockholm's central areas are also targeted by different types of crimes, with some parks becoming crime attractors (Iqbal, 2012; Knutsson, 1997). Another reason Stockholm was chosen as the present study's setting is that previous research has largely focused on American case studies. This study reports the results from a Scandinavian city for which a lack of research exists in the international literature.

The paper is organized as follows. A literature review on parks and safety issues is first presented. Parks are described as amenities and disamenities and as criminogenic places, and the impact of a park's location on housing is examined. Next the hypotheses of the study are presented. The article provides a brief description of the study area and the data. The article's focus is then directed towards the analysis used in this paper, followed by a buffer analysis and modelling of the effect of parks and crime on apartment prices. The paper concludes with an explanation of the study's limitations and suggestions for future work.

\section{Literature review}

\subsection{Parks as amenities and disamenities}

The international literature illustrates how parks are regarded as an urban amenity. Some studies have presented the positive perception towards parks as helping people come in closer contact with nature (Chiesura, 2004), whereas others have focused on the effects of the proximity of parks (Geoghegan, Wainger, \& Bockstael, 1997; McCormack, Rock, Toohey, \& Hignell, 2010) on their aesthetic value (Cho, Poudyal, \& Roberts, 2008; Geoghegan et al., 1997; Kestens, Thériault, \& Rosiers, 2004), the recreation opportunities that parks provide (Cho et al., 2008; McCormack et al., 2010; Troy \& Grove, 2008) and the types of parks that exist in urban areas (Cho, Clark, Park, \& Kim, 2009; Cho et al., 2008; Jim \& Chen, 2010; Tyrväinen \& Mäkinen, 2004; Tyrväinen \& Väänänen, 1998). A study by Jim and Chen (2010) reported that a neighbourhood park (NP) is valued more highly than a harbour view in Hong Kong.

Numerous studies have pointed out that the impact of parks, such as their impact on people's quality of life and on the perceived environmental quality of a city (Chiesura, 2004; More, Stevens, \& Allen, 1988; Tyrväinen \& Väänänen, 1998), may be difficult to quantify. Other studies have suggested that their impact is indeed tangible-for example, when a park's quality is translated into an amenity and then incorporated into a housing market through property prices. Parks often have a positive effect on housing prices (Dehring \& Dunse, 2006; Jim \& Chen, 2010; Kiel \& Zabel, 2008; Luttik, 2000; Morancho, 2003; More et al., 1988), but not always (Shultz \& King, 2001; Troy \& Grove, 2008). Parks that attract crime and exhibit signs of social problems within a neighbourhood often pull property prices down (Troy \& Grove, 2008) as they become an urban disamenity, an unpleasant quality that buyers may pay more to avoid.

\subsection{Parks as criminogenic places}

As a meeting place, a park can be an ideal setting for crimes because of the convergence of motivated offenders and potential victims in an area that lacks the presence of capable guardians (Cohen \& Felson, 1979). They suggested that in addition to an increase in the 
supply of motivated offenders, an increase in crime may be explained by an increase in criminal opportunity. Criminal opportunity comprises the availability of an attractive target and the lack of guardianship over the target. Michael, Hull, and Zahm (2001) reported that offenders may select a park that they encounter in their everyday lives. In a study of NPs in Philadelphia, Groff and McCord (2011) reported that large numbers of users in parks may act as capable guardians, which may result in a positive relationship between type and number of recreational features in parks and lower levels of crime in parks and surrounding areas. Kuo and Sullivan (2001) reported lower levels of fear, fewer incivilities and less aggressive and violent behaviour amongst residents living in 'greener' surroundings areas.

Parks may become a disamenity when they show signs of physical decay-for example, unmaintained places, litter on streets and graffiti on walls. Urban environments with physical decay are considered the most vulnerable to attracting criminals (Wilson \& Kelling, 1982). Föbker and Grotz (2006) and Herzog and Kirk (2005) reported that dark pathways in parks cause fear, especially amongst women and those who are susceptible to physical attack (e.g. the elderly and disabled). Within the Swedish context, Knutsson (1997) suggested the terms legitimate users and illegitimate users to describe users of a centrally located park in Stockholm. He found that illegitimate users are the ones who create social and physical disorder, with social disorder being any type of threatening behaviour exhibited by these park visitors (Mitchell, 1995). In addition to reporting on social disorder by rowdy groups (e.g. verbal harassment of others, public drinking and the sale and/or use of drugs and alcohol in public), Knutsson (1997) examined physical disorder, namely, the decay of urban spaces (e.g. graffiti, abandoned cars, broken windows, empty wine bottles and garbage). Physical disorder has the potential not only to change the perceptions of future homebuyers, investors, real-estate agents and insurance agents but also to shape the perceptions and behaviours of inhabitants who might intend to move to a particular neighbourhood (Sampson \& Raudenbush, 1999).

\subsection{Impact of park's location on housing market}

The international literature shows that parks affect property prices (Dehring \& Dunse, 2006; Jim \& Chen, 2010; More et al., 1988; Troy \& Grove, 2008), but they are not the only features contributing to price formation. Traditionally, the price of a property is based not only on its characteristics (e.g. size and age) but also the features of its location (e.g. city centre, water view and neighbourhood) (Rosen, 1974). These internal and external attributes may affect the area in different ways, some positively and others negatively. For instance, an apartment near a park, golf course or body of water may add value to a property, whereas one close to a noisy highway, an industrial site or a sex offender house may have its price devalued (see, e.g. Karlsson, 2008; Kryvobokov \& Wilhelmsson, 2007; Larsen, Lowrey, \& Coleman, 2003; Linden \& Rockoff, 2008). Easy access to green areas is a desirable feature, particularly to those with children or pets, but it may be less desirable if the park becomes the venue for activities that generate noise and for activities that are carried out by undesirable groups (e.g. criminals). Spatial variation in urban land use affects patterns of human interactions that are criminologically relevant in the sense that they could lead to offences (Wikström, 1991), which could potentially drive prices down.

In their 2008 study, Troy and Grove showed that the impact of parks is influenced by crime levels in the area. The proximity of parks decreases property values if local crime levels are above the national average. Moreover, if they are below that threshold, the presence of parks increases housing prices. The effects of these features also depend on 
individuals' perceptions of those qualities. Some desirable features of a park or of the location might compensate for the negative ones (e.g. parks in inner-city areas). Orford (2002) reported that spatial patterns and processes tend to operate on a variety of scales or extents. Munroe (2007) also showed that individual properties might vary widely in their values within a neighbourhood and that high or low values may simultaneously occur in different parts of the city. In addition, Can (1990) suggested that controlling for all relevant neighbourhood factors is a difficult task when assessing the effect of the neighbourhood environment on housing prices.

\section{Hypotheses of the study}

Taking into consideration the current international literature, we propose the following hypotheses for the Stockholm study case:

(1) Parks are expected to affect apartment prices positively. Thus, as distance from parks increases, property prices decrease.

(2) The effect of proximity to parks on apartment prices may depend on the characteristics and/or amenities associated with them. For instance, parks are valued more by buyers when they serve multiple functions and provide green space, playgrounds (PGs) and sports fields.

(3) Crime is an indication of a lack of safety and is considered a disamenity, which means that safe parks with low crime rates are expected to maintain their positive influence on the prices of surrounding properties. However, the positive influence of parks on property prices is transformed into a negative one if these parks have high crime rates.

(4) Because parks located at or near the city centre are often in high demand owing to the high population density of those areas, they may have a more positive impact on property prices than parks located on the periphery of Stockholm, where parks are not a rare commodity.

\section{The study area}

Stockholm is rich in parks. In 2010, the city was granted the European Green Capital Award by the European Union (EU) Commission as Europe's first 'green capital'. Parks and green spaces cover $40 \%$ of the land area of the municipality of Stockholm, and water comprises 10\% (Stockholm City Plan, 2009). Stockholm's 1,046 parks and green spaces are classified under three major categories (Stockholm Park Programme, 2006; for more detail, see Appendix 1).

Parks are further subdivided based on various characteristics. NPs (19\%), large natural area parks (LNPs) (19\%) and PGs (18\%) predominate, whereas square parks (SPs), beach parks (BPs) and community garden plots (CGPs) make up 4\% of Stockholm's parks. Inner-city parks (ICPs), hilly parks (HPs), port parks (PPs) and cemeteries (CMs) comprise only $1 \%$ of the municipality of Stockholm. The remaining parks (28\%) are miscellaneous types of parks (sociotope map: for more detail, see Ståhle, 2006).

The population of Stockholm County was 864,324 inhabitants in 2011. If the high growth rate continues, the population is expected to increase to 933,961 inhabitants by 2016 (Statistiska centralbyrån [SCB], 2013). Although more than half of all apartments are located in the city centre, there remains a high demand for apartments within the central part of Stockholm. To meet this demand, various construction companies have constructed new buildings and converted old ones into apartment buildings in central Stockholm. The 
city centre is also home to Stockholm's major shopping amenities as well as museums, theatres, bars, restaurants and cinemas. The main transport hub is also located in the city centre, and all underground train lines pass through it. Relatively high criminogenic areas, such as Kulturhuset (Stockholm's cultural centre) and Sergels torg (the most central public square in Stockholm), are also situated nearby (Ceccato, Haining, \& Signoretta, 2002; Ceccato \& Wilhelmsson, 2011).

Stockholm is a relatively safe city in comparison to other cities in Europe (Eurostat, 2012). Approximately 192,723 offences (excluding narcotics and penal code offences) were reported in Stockholm in 2012. Offences such as pickpocketing, fraud with the help of the Internet and unauthorized access to or use of computer systems increased the most in 2012. Crimes against the person, assaults, unlawful threats, non-sexual molestation and sexual offences also increased (Brottsförebyggande rådet [Brå], 2013). According to Stockholms Stads Utrednings- och Statistikkontor (USKAB, 2013), about 16\% of vandalism is reported in Stockholm. Assaults, robbery and burglary and various types of theft comprise $25 \%$ of all reported crime (including car thefts, shoplifting and bank robberies). Crimes against the person, mainly violent crimes such as assault and sex crimes, comprise $8 \%$ of total reported crime. Traffic offences without drugs represent $8 \%$ of all reported crime, and 5\% of reported crime is categorized as fraud in Stockholm (USKAB, 2013).

\section{Data}

The data were obtained from a number of different sources. These sources are as follows:

(1) Property price data were collected by Svensk Mäklarstatistik AB, a real-estate broker association that covers around $70-80 \%$ of all broker transactions in Stockholm based on transactions of apartments in cooperative housing societies in Stockholm, Sweden. Data collected during a 1-year period (from January 2008 through December 2008) were used in this study. The data consisted of 9,622 apartment transactions. To simplify the analysis (spatial weight matrix), $7 \%$ of multiple addresses were excluded, and only one transaction (the first transaction in 2008) for $x, y$ coordinates was kept. The finalized database consists of 8,938 transactions involving the sale of apartments. The data-set includes area code, property address, selling price, year of construction, living area, price per square metre, presence of balcony, date of contract, number of rooms, monthly fee to the cooperative, number of the floor of the specific apartment, postal code, total number of floors and $x$ and $y$ coordinates. The typical apartment sample was 50 years old. Newly built apartments comprised only $2 \%$ of the sample. More than $50 \%$ of the apartments were built between 1900 and 1945. The monthly maintenance fee was about SEK 3,000 per month. A large number of apartments were approximately $62 \mathrm{~m}^{2}$ in size with 2.3 rooms, excluding the kitchen. The average price value of an apartment was SEK 2.3 million. The data from real-estate broker statistics were merged with the data from USKAB and the Stockholm Police Department. (For definitions of variables, see Appendix 2.)

(2) Park data were obtained from the Stockholm City Planning Office. The data consisted of information on 1,046 parks. The data-set includes park name, area, district name in which the park is located, types of parks and 38 other park characteristics, including the presence of skating rinks, picnic areas, green sanctuaries, pleasant scenery, nature experiences, flower beds, large bodies of 
water (e.g. ponds and lakes), social events, CGPs, water fountains, scenic views, PGs, natural areas and ball fields. The data-set also includes neighbourhood attributes/characteristics-for example, proximity to waterfront, parks, underground stations and main roads. To the best of our knowledge, there are no data available on the use of parks by population in Stockholm.

(3) Field survey data were collected by the first author of this article in selected parks in Stockholm during a pilot study in 2011. The aim behind the fieldwork was to gather practical information about what constitutes a 'park'. Based on fieldwork data, park characteristics are categorized as either amenities or disamenities, with functions, aesthetical features, location and management (safety and security situation) as the main categories. The parks were inspected at two different points in time-in late winter of 2011 and in the summer of 2011 (Figure 1). A checklist was created for categorizing the parks as either an environmental amenity or an urban disamenity. Deciding whether to categorize an open space as an amenity or disamenity was not straightforward because those amenities and disamenities were especially difficult to differentiate. The functions category includes areas for swimming, picnicking, sunbathing, jogging, dog walking, meeting, transition, biking and play. The aesthetical features category describes pleasantness, views and a sense of comfort. The location function refers to the proximity to water, the urban centre and other special places as well as to the types of surroundings (e.g. commercial). Good management and all the other mentioned characteristics are considered to be environmental amenities, whereas crimes, the safety and security situation, mismanagement, smell, darkness, lack of function, litter and the presence of teenage gangs are considered to be urban disamenities in parks.

(4) Crime data obtained from the police department in Stockholm included crime statistics data (e.g. the number of acts of vandalism per square metre of area or number of acts of outdoor violence per 10,000 inhabitants). Crime data for 2008 were obtained from the crime database maintained by Stockholm Police. These data were the total number of crimes, robberies, assaults, acts of
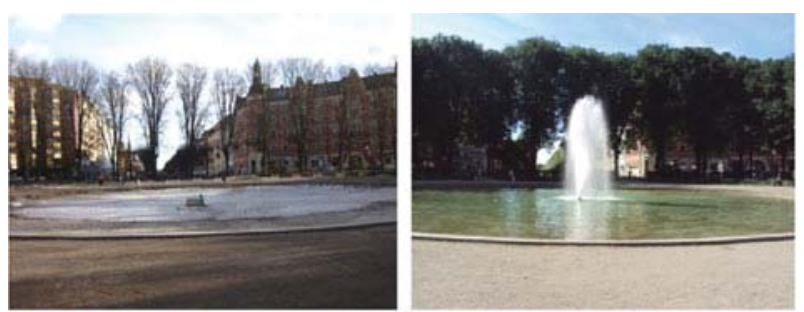

\begin{tabular}{ll}
\hline Amenities & Disamenities \\
\hline Jogging & Close to a major road
\end{tabular}

\section{Dog walking Noise \\ Meeting place Drunk people}
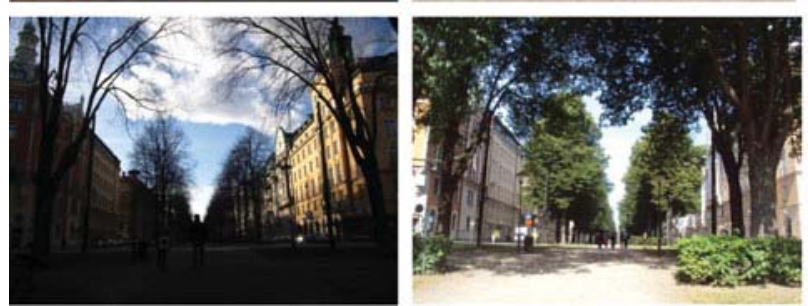

Green areas Violence

Transition area Vandalism

Good

management

Near to Metro

station

Figure 1. Fieldwork inspection (winter/summer) in Karlaplan, an inner city park. Source: Fieldwork (2011). 
vandalism, acts of violence, residential burglaries, drug-related offences and thefts, including thefts of cars and thefts from cars. Stockholm Police provided data for crimes that occurred in small unit areas known as basområde (the smallest geographical unit for statistical data in Sweden). In 2006, the municipality of Stockholm was divided into 408 units. The term was introduced by USKAB in 1990 as a replacement for the previously used term FOB area (for more detail, see Ceccato \& Wilhelmsson, 2011). Rates per small unit areas were calculated for the total number of crimes, robberies, acts of vandalism, acts of violence, residential burglaries, shoplifting incidents, drug-related offences, thefts, thefts of cars, thefts from cars and assaults by total population (for definitions of variables, see Appendix 2). These rates were associated to each park (as absolute number of crime would not control for the population at risk). Wikström (1991) previously discussed the inappropriateness of using total population as the denominator when calculating crime rates.

\section{Analysis}

The analysis of this study is divided into two sections: an exploratory buffer analysis of parks and crime and apartment prices, followed by an assessment of the effect of parks and crime on apartment prices using hedonic modelling. Both sections introduce the employed methodology and then discuss the results.

\subsection{Buffer analysis of parks and crime}

In spatial analysis, buffer analysis is used for identifying areas surrounding a specific geographic feature, for instance, a park. The process involves generating a buffer (a zone of a particular distance around a specific geographic feature) and then identifying or selecting features based on whether they fall inside or outside the boundary of the buffer or to what distance they may occur from that pair of coordinates.

In this study, 40 parks were selected for the detailed buffer analysis (Figure 2(a), polygons in black). The selection was based on the three major types of parks identified by the Stockholm Park Programme (2006) (Appendix 1). Stockholm was split into four quarters from the city centre, and then 10 parks in each quarter were randomly selected using geographical information systems (GIS). Parks in Stockholm vary in size (ranging from 1,999 to $302,061 \mathrm{~m}^{2} ; M=41,381.65 \mathrm{~m}^{2}$; $\mathrm{SD}=52,937.611 \mathrm{~m}^{2}$ ). Parks were assigned to one of the following categories: PGs, LNPs, NPs, ICPs, HPs, SPs, BPs, PPs, CGPs, CMs and schoolyards (SYs). Of the 40 selected parks, 7 were PGs, 8 were LNPs, 8 were NPs, 5 were HPs, 4 were ICPs, 2 were SPs and 2 were BPs. The other miscellaneous parks were CMs, CGPs, SYs and PPs. To check the prices of apartments around the parks, three buffers from the park boundary were created using a GIS for 50, 100 and $150 \mathrm{~m}$, with the last buffer covering a distance of more than one city block from parks (Figure 2(b)). A block distance is around $100 \mathrm{~m}$, depending on its location. A 50-m buffer was chosen as the smallest buffer distance so as to have enough apartments within walkable distance in each band. Because parks are located very close to one another in the city centre of Stockholm, the threshold of a 150-m buffer was chosen so as to avoid the risk of overlaps between the areas of influence of two parks.

For each park type, average prices per square metre were checked from 50 to $100 \mathrm{~m}$ and from 100 to $150 \mathrm{~m}$. The expectation was that the proximity of parks has a positive, but declining, impact on apartment prices. To investigate the effects of crime in parks on 
(a)

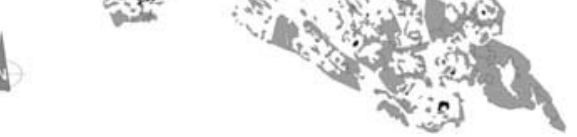

(b)

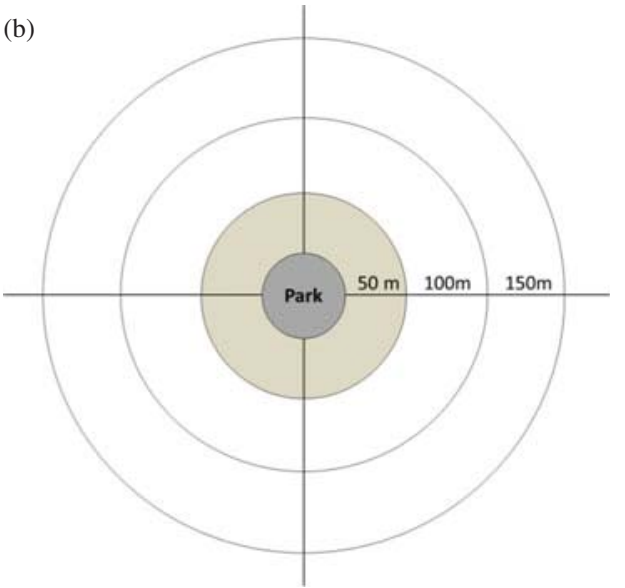

(c)

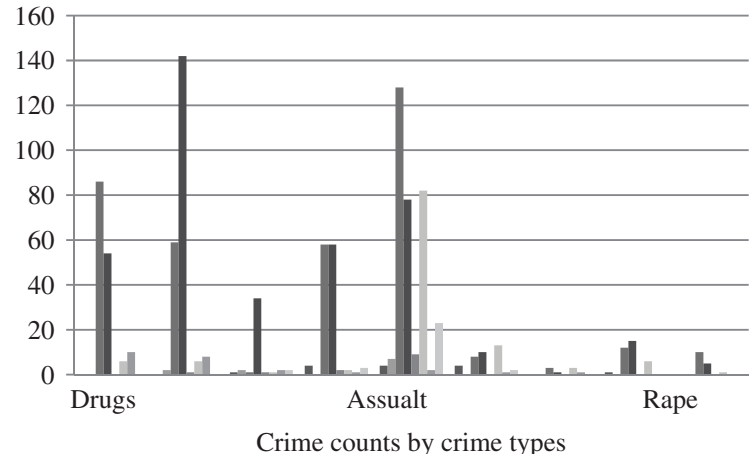

- Playgrounds

Neighbourhood parks

Hilly parks

- Inner city parks

- Square parks

Figure 2. (a) Selected parks $(N=40)$ as study areas (b) three buffers size in relation to park location. (c) Crime counts in parks. Source: Stockholm city planning office and Stockholm County Police, 2008.

apartment prices, two different methods were employed to describe the crimes. First, crime counts were checked in relation to the park areas. Second, crime rates were checked by making comparisons with the median of the crime rates for the entire city of Stockholm. We limited the analysis to crime incidents to only those that happened within parks.

Based on the prices of apartments located near 40 different parks, it appears that the farther away an apartment is located from a park, the greater the decrease in its price. Table 1 shows that apartment prices decreased by $10 \%$ within $100 \mathrm{~m}$ of a park and by $18 \%$ within $150 \mathrm{~m}$ of a park. Although based on a small sample, these findings are indicative that parks are perhaps amenities that are incorporated in property prices. Most prices seemed to decrease for apartments located farther away from a park. However, there are exceptions. Large parks/forests, such as LNPs and PPs, often had either little effect or even a negative one on the prices of apartments in the immediate vicinity. The negative effect of LNPs may be indicative of interstitial spaces that transform into unusable spaces and, as a consequence, have the potential to become magnets for litter and graffiti. Parks that are CGPs are not considered public spaces (their use is limited to their owners), and therefore are not a public good. Another possible reason for this negative effect may be related to the fact that these areas are perceived as obstacles to accessibility to other parts of the city. 
Small parks, such as NPs, are highly valued because they are accessible by foot and are used by both residents and city transients. Most of these parks are known by name and form part of the city's identity (e.g. Årstastråket and Tidaholmsparken). According to the results, prices were the highest for apartments that were located close to a park; these prices then decreased as the distance increased: Within $100 \mathrm{~m},+5 \%$ increases in prices were noticed, whereas a decrease of $-31 \%$ was detected within $150 \mathrm{~m}$ from the NP (Table 1).

The buffer analysis of selected parks indicates that parks might have a positive effect on apartment prices; however, this effect is somewhat influenced by neighbourhood characteristics (e.g. crime) and city context (whether parks and apartments are located in inner-city areas or peripheral areas). To investigate this issue further, we examined the incidence of crime in each park. As shown in Table 1, more serious crimes including violence, drugs, assault and graffiti occurred within ICPs (Humlegården, Vasaparken and Tennisparken) in Stockholm, but it is important to note that not all parks were places of crime. Some parks-especially the more central ones, such as Tantolunden, Observatorielunden and Vasaparken-had more crimes than others, but the impact of these crimes cannot be generalised for the whole Stockholm or by crime type. For example, although HPs and ICPs had the highest concentrations of crime, they seemed to have little effect on prices or, at least, their effect was not detectable in this sample. In the next section, hedonic models are used to test the effects of parks and crime on the whole municipality of Stockholm. The unit of analysis is 8,938 apartment sales ( $x$ and $y$ coordinates), and parks and crime rates are considered part of the area context (polygons).

\subsection{Modelling the effects of parks and crime on apartment prices}

One way to analyse property values while accounting for property location and neighbourhood characteristics is to use hedonic price models. A hedonic price model is one that breaks down the price of an item into separate components that determine the price. For example, the price of a house may depend on its size, its location and other factors. Rosen (1974) suggested that hedonic price models are based on the principle that goods are not homogenous and that they differ in numerous attributes, which can be implicitly revealed by observed differences in prices. In the case of an apartment, preferences for various attributes are revealed through the price that one implicitly pays for these attributes, which can be expressed as follows:

$$
y=\beta x+\varepsilon,
$$

where $y$ is a vector of observations on the sales price; $x$ is a matrix of observations on the property attributes and the neighbourhood characteristics, such as features of park and crime; $\beta$ is the associated vector of regression coefficients (the marginal implicit price of each attribute); and $\epsilon$ is a vector of random error terms.

Independent variables in these models are related to different environment characteristics and other individual variables to which the property is exposed and to how these characteristics may add to or subtract from the value of the property. However, there is no consensus on which set of relevant characteristics of the city structure and environment should be selected for price determination so that it accurately reflects the characteristics of the property and the features of the neighbourhood and city context. In this study, hedonic analysis was performed by regression analysis between apartment 


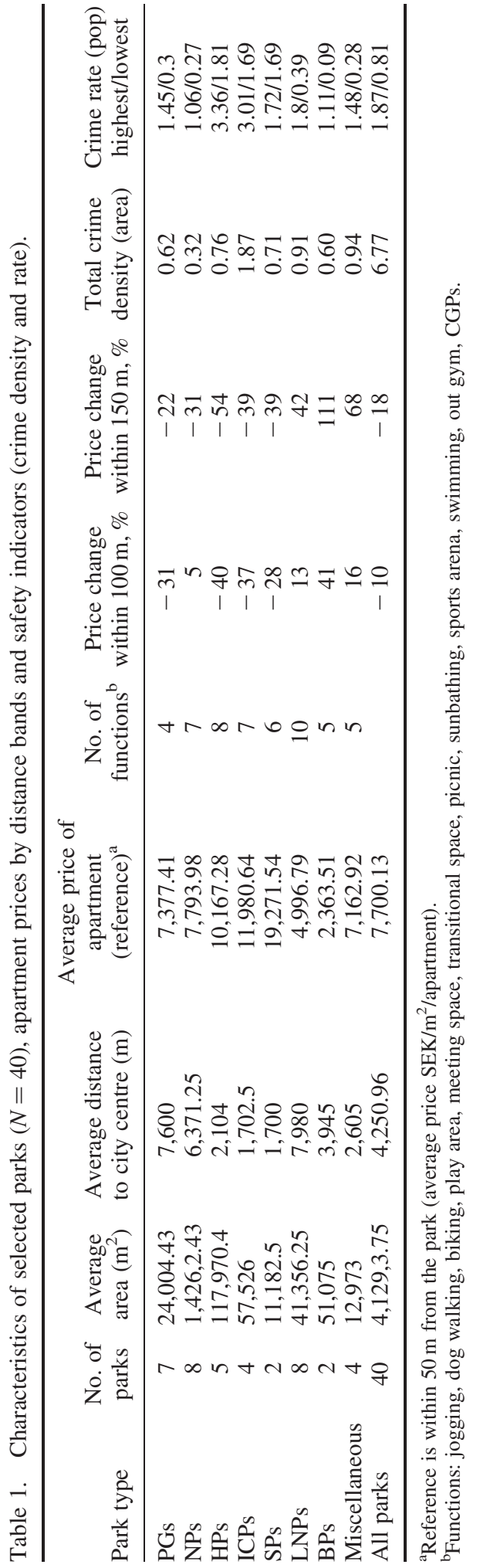


price and a number of countable attributes, including house structure properties, park characteristics, neighbourhood characteristics and crime rates.

Four types of models constituted the basis of the analysis. The sales price was regressed against a series of countable attributes, including house structure properties, park characteristics, neighbourhood characteristics and crime rates individually. No interaction term was introduced to combine independent variables. The benchmark model included all variables related to apartment characteristics and neighbourhood characteristics-for example, time period dummies (months and location variables), building age, selling price, living area, presence of balcony and elevator, number of rooms, number of the floor of the specific apartment, total number of floors, distance to city centre and proximity to the metro, major highways, train stations, main roads and streets and water $(100-500 \mathrm{~m})$.

The total number of variables used in the benchmark model was 46 , and the total number of observations was 8,938. A second set of models was then used to test the effects of parks on apartment prices. The models included all variables from the benchmark model plus parks. An aggregate variable for parks was tested as well as those variables indicating particular functions of parks. For instance, parks with social events or PGs were modelled as dummy variables separately. A third set of models tested the effects of parks and crime on apartment prices. The models included a crime variable as total crime rate per 10,000 inhabitants in each zone. Crime variables were created by selecting the upper quartiles of each crime rate as they would potentially indicate only places with more problems. Using a GIS, we created Dirichlet polygons from each coordinate of apartment sales. These polygons were overlapped with park polygons; those polygons with a park 'received' all attribute values of that park, including crime rates and apartment transaction data. An aggregate park variable means that if the polygon in which the property is located receives a park, it is denoted by a 1 ; a 0 indicates no park is received. To estimate the models, the dependent variables were log transformed, as suggested by Halvorsen and Pollakowski (1981) and Court (1939). The data-set was subsequently imported into GeoDa version 1.4.6 to generate the weight matrix. To represent the spatial arrangement of the city using GeoDa, binary weight matrices based on shared common boundaries or vertices were created. These binary weight matrices were then used to create the exogenous covariate (lag variable) based on the natural log of the original crime rate. This was carried out in GeoDa using lag operations (for more detail, see Ceccato \& Wilhelmsson, 2011).

Real-estate data are highly spatially dependent (Song \& Wilhelmsson, 2010). Even if spatial effects are taken into account, the hypothesis of no spatial autocorrelation cannot be rejected (Song \& Wilhelmsson, 2010). All neighbourhood attributes, park characteristics and crime rates were then tested for possible correlations between residuals. Multicollinearity was tested using GeoDa. In addition, heteroscedasticity (the variance of the error term) was checked with the Breusch-Pagan test and the Koenker-Bassett test using GeoDa. After the presence of spatial dependence was identified, spatial lag and spatial error models were used in the fourth set of models. As stated by Anselin (1988), the spatial dependence between observations can be incorporated in two ways: The model may contain a spatially lagged dependent variable (spatial lag model), or the model may incorporate a spatial autoregressive process in the error structure (spatial error model). The appropriateness of the spatial lag model and the spatial error model has been discussed in detail by Anselin. To achieve unbiased and efficient estimates for the regression parameters in the model, it is necessary to conduct spatial lag and spatial error models so as to ensure more reliable results (Ceccato \& Wilhelmsson, 2011). 
Most of the variables (living area, presence of balcony, elevator, year of construction and number of rooms) included in the benchmark model are highly significant and show the expected sign (e.g. size effects on prices) and are of reasonable magnitude. According to the results, the effect of parks is dependent on the type of green area. The aggregate measure for parks (1, having a park; 0 , not having a park) has a negative impact on apartment prices; in some cases, this effect becomes positive when parks are categorized by type or functionality. The model results indicate that some types of parks had a positive impact on housing prices: parks that have certain characteristics such as features of national interest, cultural features and a 'forest feeling' (i.e. nature amidst the concrete jungle) and parks that encourage intimate use by city dwellers and offer recreational activities such as skating are positively appreciated in the housing market. By contrast, parks that offer other types of recreational use (e.g. ball games, golf, PGs, swimming and water activities), that play host to social events and that are used for cultivation purposes negatively affect housing prices. (Table 2 explains the results from the ordinary least squares [OLS] regression model with selective park variables.)

Interestingly, most of the water-related activities, which were expected to have a positive impact on property values, were actually found to decrease housing prices in Stockholm. This was the case for large bodies of water and associated facilities, such as ponds with fishing, lakes, marinas, boating and swimming facilities. Overall, the modelling results for the whole city confirmed those found for the apartments located near the sample of 40 selected parks.

According to the analysis, the impact of crime in parks on apartment prices depended on the type of crime and the type of surrounding area. The findings from the OLS model showed that parks as an aggregate measure still exhibited a negative impact on apartment prices; however, with crime added to the model, its impact became stronger. The results indicate that parks in areas with high rates of violence have greater impact on apartment prices than parks in areas with high rates of vandalism and high rates of total crime. (Table 3 explains the results from the OLS and error models with selective park and crime variables).

Since some of the parks had varied effects on apartment prices, four types of parks were selected to be tested together with crime rates (two types of parks with a positive effect and two types of parks with a negative effect). Parks with features of national interest and a forest feeling were selected for their positive impact on prices, and parks with ball fields and PGs were selected for their negative impact on prices (Table 3). Each type of crime was tested individually with each type of park. The results show that all park variables had the same original signs (positive or negative) after the crime variables were added to the model.

All OLS models showed problems of autocorrelation of the residuals (Moran's I value is significant). A common practice is to fit either a spatial lag model or a spatial error model. The spatial lag model includes a lagged form of the response variable as one of the independent variables (for more detail, see Ceccato \& Haining, 2005). Both types of spatial models were extensively tested, and the results were compared. These two models are similar in statistical terms, and choosing between them by simply inspecting the diagnostics from the OLS model may be a difficult task. Because the spatial error model showed indications of better performance (based on log-likelihood [LIK] and Akaike information criterion [AIC] values), the discussion will be based only on the results of the spatial error model (Table 3).

The positive sign of the variable of park changed to negative when crime variables were added to the spatial error model, and the positive sign of a forest feeling changed to negative when violence and vandalism were added to the spatial error model. For parks 


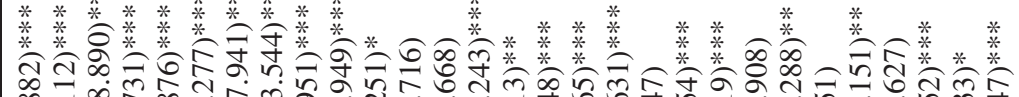

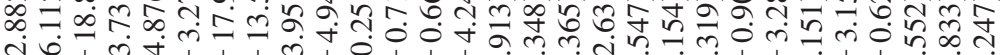

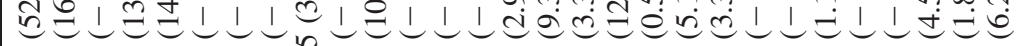

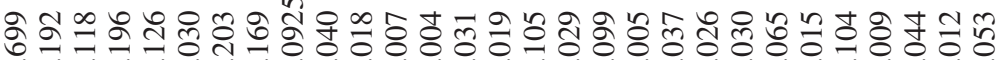

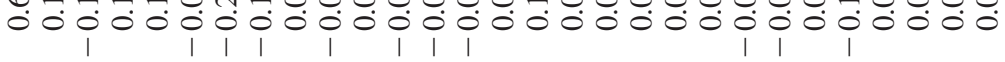

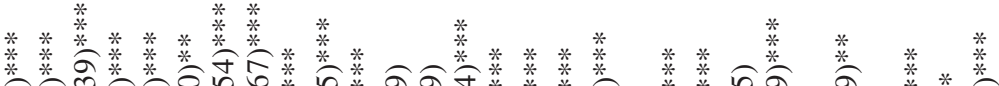

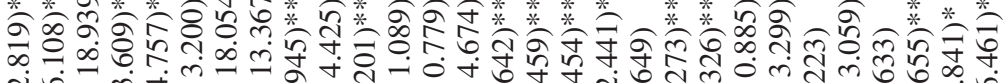

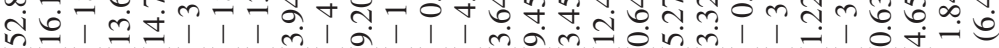

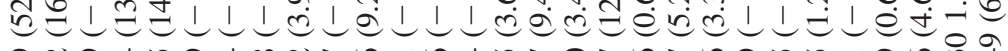

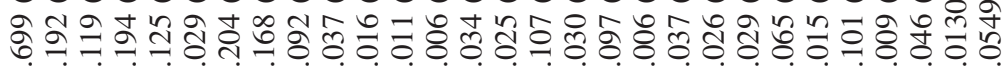

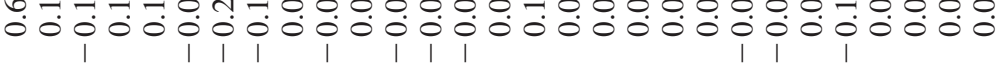

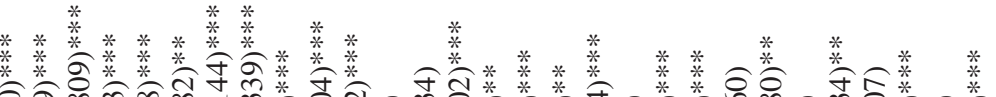

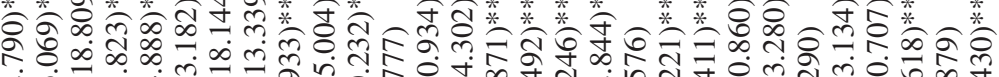

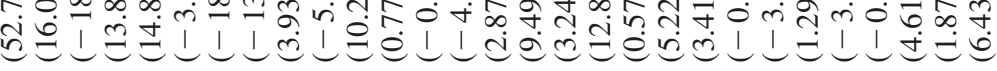

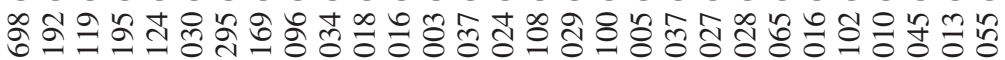

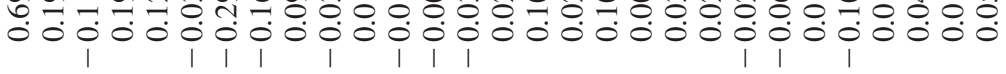

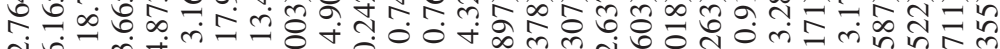
n్n

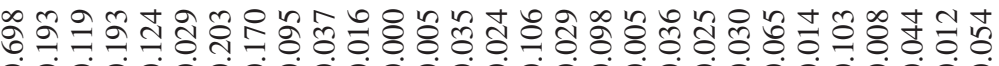

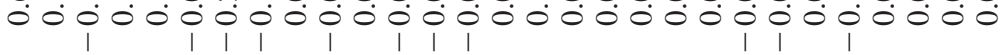

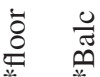
ซ

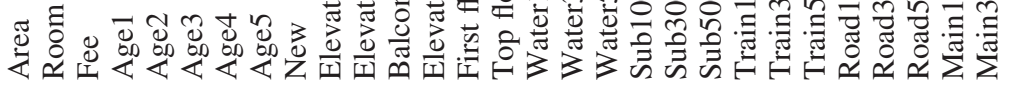


Table 3. Hedonic models (OLS and error) for parks and crime.

\begin{tabular}{|c|c|c|c|c|}
\hline \multirow[b]{2}{*}{ Variable name } & \multicolumn{4}{|c|}{ OLS coefficient ( $t$-value) error coefficient ( $z$-value) } \\
\hline & Model park & Model violence & Model vandalism & Model total crime \\
\hline \multirow[t]{2}{*}{ Park } & -0.032 & -0.031 & -0.032 & -0.032 \\
\hline & $(-3.921) * * *$ & $(-3.758) * * *$ & $(-3.870) * * *$ & $(-3.862) * * *$ \\
\hline \multirow{3}{*}{$\begin{array}{l}R^{2}(\mathrm{OLS}) \\
\text { LIK (AIC) }\end{array}$} & 0.765 & 0.768 & 0.766 & 0.766 \\
\hline & -426.138 & -358.041 & -404.361 & -405.333 \\
\hline & $(940.275)$ & $(806.083)$ & $(898.722)$ & $(900.665)$ \\
\hline \multirow{3}{*}{$\begin{array}{l}\text { Moran's I } \\
\text { Error model }\end{array}$} & $0.503 * * *$ & $0.493 * * *$ & $0.499 * * *$ & $0.499 * * *$ \\
\hline & 0.009 & -0.009 & -0.009 & -0.008 \\
\hline & $(-1.398) *$ & $(-1.408) *$ & $(-1.405) *$ & $(-1.390)^{*}$ \\
\hline \multirow{3}{*}{$\begin{array}{l}R^{2} \text { (error) } \\
\text { LIK (AIC) }\end{array}$} & 0.884 & 0.884 & 0.885 & 0.884 \\
\hline & $2,047.490$ & $2,047.937$ & $2,050.920$ & $2,047.592$ \\
\hline & $(-4,006.98)$ & $(-4,005.87)$ & $(-4,011.84)$ & $(-4,005.19)$ \\
\hline \multirow{5}{*}{$\begin{array}{l}\text { Features of } \\
\text { national interest } \\
R^{2} \text { (OLS) } \\
\text { LIK (AIC) }\end{array}$} & 0.148 & 0.152 & 0.145 & 0.152 \\
\hline & $(4.463) * * *$ & $(4.625) * * *$ & $(4.376) * * *$ & $(4.589) * * *$ \\
\hline & 0.765 & 0.768 & 0.766 & 0.766 \\
\hline & -423.861 & -354.397 & -402.268 & -402.251 \\
\hline & $(935.722)$ & (798.793) & $(894.536)$ & $(894.503)$ \\
\hline \multirow{3}{*}{$\begin{array}{l}\text { Moran's I } \\
\text { Error model }\end{array}$} & $0.503 * * *$ & $0.493 * * *$ & $0.500 * * *$ & $0.499 * * *$ \\
\hline & 0.060 & 0.060 & 0.058 & 0.060 \\
\hline & $(2.365)^{*}$ & $(2.371)^{*}$ & $(2.282)^{*}$ & $(2.358) *$ \\
\hline \multirow{3}{*}{$\begin{array}{l}R^{2} \text { (error) } \\
\text { LIK (AIC) }\end{array}$} & 0.884 & 0.884 & 0.885 & 0.884 \\
\hline & $2,049.308$ & $2,049.755$ & $2,052.536$ & $2,049.404$ \\
\hline & $(-4,010.62)$ & $(-4,009.51)$ & $(-4,015.07)$ & $(-4,008.81)$ \\
\hline \multirow[t]{2}{*}{ Forest feeling } & 0.077 & 0.074 & 0.078 & 0.077 \\
\hline & $(2.647) * * *$ & $(2.55) * * *$ & $(2.71) * * *$ & $(2.66) * * *$ \\
\hline$R^{2}(\mathrm{OLS})$ & 0.765 & 0.768 & 0.766 & 0.765 \\
\hline \multirow[t]{2}{*}{ LIK (AIC) } & -433.228 & -364.867 & -411.212 & -412.244 \\
\hline & $(954.456)$ & $(819.734)$ & $(912.425)$ & $(914.487)$ \\
\hline Moran’s I & $0.504 * * *$ & $0.494 * * *$ & $0.500 * * *$ & $0.500 * * *$ \\
\hline \multirow[t]{2}{*}{ Error model } & 0.015 & -0.022 & -0.020 & 0.015 \\
\hline & $(1.022)$ & $(-2.697)^{* *}$ & $(-2.396) *$ & $(1.022)$ \\
\hline$R^{2}$ (error) & 0.884 & 0.884 & 0.884 & 0.884 \\
\hline \multirow[t]{2}{*}{ LIK (AIC) } & $2,047.036$ & $2,050.549$ & $2,052.780$ & $2,047.148$ \\
\hline & $(-4,006.07)$ & $(-4,011.1)$ & $(-4,015.56)$ & $(-4,004.3)$ \\
\hline \multirow[t]{2}{*}{ Ballgames } & -0.099 & -0.096 & -0.098 & -0.100 \\
\hline & $(-5.151) * * *$ & $(-5.047) * * *$ & $(-5.136) * * *$ & $(-5.209) * * *$ \\
\hline$R^{2}(\mathrm{OLS})$ & 0.765 & 0.769 & 0.766 & 0.766 \\
\hline \multirow[t]{2}{*}{ LIK (AIC) } & -420.541 & -352.351 & -398.644 & -399.209 \\
\hline & $(929.083)$ & (794.702) & $(887.287)$ & $(888.418)$ \\
\hline Moran's I & $0.503 * * *$ & $0.493 * * *$ & $0.500 * * *$ & $0.499 * * *$ \\
\hline \multirow[t]{2}{*}{ Error model } & -0.044 & -0.045 & -0.044 & -0.044 \\
\hline & $(-3.054) * *$ & $(-3.061)^{* *}$ & $(-3.038) * *$ & $(-3.054) * *$ \\
\hline$R^{2}$ (error) & 0.884 & 0.884 & 0.885 & 0.884 \\
\hline \multirow[t]{2}{*}{ LIK (AIC) } & $2,051.204$ & $2,051.626$ & $2,054.544$ & $2,051.285$ \\
\hline & $(-4,014.41)$ & $(-4,013.25)$ & $(4,019.09)$ & $(-4,012.57)$ \\
\hline \multirow[t]{2}{*}{ PG } & -0.077 & -0.072 & -0.073 & -0.076 \\
\hline & $(-4.259) * * *$ & $(-3.990) * * *$ & $(-4.023) * * *$ & $(-4.181) * * *$ \\
\hline$R^{2}(\mathrm{OLS})$ & 0.765 & 0.768 & 0.766 & 0.766 \\
\hline LIK (AIC) & -424.75 & -357.14 & -403.759 & -404.046 \\
\hline & $(937.499)$ & $(804.279)$ & $(897.518)$ & (898.093) \\
\hline Moran’s I & $0.503 * * *$ & $0.493 * * *$ & $0.500 * * *$ & $0.499 * * *$ \\
\hline Error model & -0.024 & -0.024 & -0.023 & 0.024 \\
\hline & $(-1.782)^{*}$ & $(-1.789) *$ & $(-1.738) *$ & $(-1.777)^{*}$ \\
\hline$R^{2}$ (error) & 0.884 & 0.884 & 0.885 & 0.884 \\
\hline LIK (AIC) & $2,048.100$ & $2,048.546$ & $2,051.443$ & $2,048.203$ \\
\hline & $(-4,008.2)$ & $(-4,007.09)$ & $(-4,012.89)$ & $(-4,006.41)$ \\
\hline
\end{tabular}


that already had a negative impact on prices, crime did not seem to have an additional impact as the negative effect continued to be of the same magnitude as before (with parks only) (Table 3).

\section{Discussion}

Our initial assessment of 40 parks in Stockholm reveals that parks as an amenity are incorporated into housing prices. In the real-estate market, apartments located near parks are valued more. The average price per square metre decreases as the distance from parks increases (a $10 \%$ decrease within $100 \mathrm{~m}$ of a park, and an $18 \%$ decrease within $150 \mathrm{~m}$ of a park). This is particularly valid for smaller NPs. However, there are exceptions, thus indicating that parks may also be viewed as a disamenity. For instance, larger green areas, LNPs, BPs, PPs, CGPs and forests sometimes have either little effect on housing prices or a negative one. These results are in line with those reported in a study by Jim and Chen (2010) in Hong Kong, showing that 'easy access to a neat, well managed, and relatively safe NP is more preferred than harbour view or untamed mountains' (p. 667). This could also relate to the broken windows metaphor (Wilson \& Kelling, 1982). Because of the large area involved, some parks are not easy to maintain, and if things are left unrepaired, broken or vandalized in parks, they foster an atmosphere of disorder and can affect property prices negatively.

The results from the hedonic modelling confirm the initial evidence of a relationship between the price value of an apartment and the characteristics of a park, but some aspects of this relationship are unexpected. The aggregate measure for parks (1, having a park; 0 , not having a park [for more detail, see section 'Modelling the effects of parks and crime on apartment prices', paragraph 5]) does affect apartment prices negatively. Some characteristics of parks may produce social activities that are viewed as urban disamenities. For example, the presence of a marina or boating facilities may increase noise levels. Another characteristic of parks shown to affect apartment prices negatively is the poor maintenance of interstitial spaces (e.g. LNPs), which may entice individuals to litter and to consume alcohol within these parks.

Moreover, the results indicate that the aggregate measure for parks is not suitably constructed to depict the quality of parks; perhaps, this measure is not accurate enough to acquire its effect when joined with housing polygons. This result shows that adding a variable that 'summarizes' the combined function of park qualities is perhaps not a good indicator of amenity because some parks have a positive impact on prices and others have a negative one. In a more technical account, findings show that, taken together, all these measures mentioned previously may generate a deleterious effect, which may produce another factor that is not in the model (therefore, it comes up as significant and negative in most models).

PGs and SYs are considered valuable assets in Stockholm. The results of the present study show that people are willing to pay more for apartments that are near PGs and SYs. Thus, the results are generally consistent with the findings of several studies on schools and home values showing that living near a school is considered a public amenity that affects property prices (Dubin \& Goodman, 1982; Goodman \& Thibodeau, 1998; Kong, Yin, \& Nakagoshi, 2007). When buying a property, families with small children or couples who want to start families include schools in their list of amenities that they view as important. Previous research has also revealed higher property values in those areas with a better education environment (Kong et al., 2007, p. 246), which may coincide with the availability of green areas for children. 
Some park characteristics such as features of national interest and cultural features increase apartment prices, whereas other park attributes such as the presence of golf courses, skating rinks and ball fields and the hosting of social events decrease housing prices. Traffic, noise and safety concerns associated with parks negatively affect apartment prices, and thus might be perceived as disamenities. These findings corroborate the second hypothesis, which states that the effect of proximity to public parks on apartment prices may depend on the characteristics and/or amenities associated with these parks. With reference to the impact of crime in parks on apartment prices in Stockholm, our results confirm the third hypothesis, which suggests that parks with high crime rates (or parks located in a section of the city with a high crime rate) have a negative effect on property prices. Three types of crime-vandalism, violence and total crime-were tested. The results show relatively high crime rates in the city centre, indicating a negative impact on housing prices. In addition, the results indicate that the rate of violence is considerably higher than the rates of vandalism and total crime in parks. As expected, parks with social events, cultural features and open-air cafés tend to have higher rates of violence but not all of them.

Parks with PGs, SPs and NPs had comparatively low crime rates. These findings are in line with the routine activity theory (Cohen \& Felson, 1979). Interestingly, the presence of capable guardians-in the form of participants, users, coaches and parents and their children and teenagers in activities at small parks with PGs-plays an important role in maintaining low crime rates. However, research has also showed that even within large groups of individuals, capable guardians are not always present (Piza \& Kennedy, 2003). The results for Stockholm (a forest feeling and features of national interest) also show that the positive sign of the variable of park switched to negative when crime variables were added to the model.

As expected, the results show that in relation to the city centre, the geographical size of a park (e.g. Tantolunden, a large park located in the southern part of central Stockholm) does not affect housing prices (Morancho, 2003); however, the location of a park does. Early results from the present study suggested that the proximity of parks to the city centre (without considering the size or type of park) has a positive impact on property values. This finding supports the fourth hypothesis, which states that apartments located close to parks near/within the city centre have a higher selling price (e.g. Observatorielunden and Vasaparken) than apartments located close to parks on the periphery of Stockholm (e.g. Senoren, Stråket and Viljan). It is equally important to note that on the periphery of Stockholm, high crime rates and lower housing prices may be a common feature. High crime rates lead to decreased apartment prices, thereby attracting groups with weak resources into the area.

\section{Final considerations}

This study assesses whether parks affect apartment prices with respect to the attributes of apartments and neighbourhoods, with a focus on the effects of crime. The study started with an analysis of a sample of parks. Four hypotheses were then tested using buffer analysis and hedonic modelling. The study shows that as the distance from parks increases, property prices decrease. The effect of proximity to a park is also dependent on the amenities associated with that type of park, the neighbourhood and the city context. Some parks such as smaller NPs generally have a positive impact, whereas the effect of larger parks is the opposite or non-existent, especially in the most peripheral parts of the city. The 
study also shows that property prices are the highest around parks but they decrease around parks that are magnets for certain types of crimes.

This study contributes to the existing literature in many ways. It provides evidence that buyers in Stockholm may be willing to pay extra for an apartment that is in close proximity to a park; their willingness to do so depends on the type of park and the location of the park within the city. The evidence is based on data from fieldwork/selected parks and on secondary data used in the models that take space into account using a GIS and spatial modelling.

However, this study has some limitations regarding crime and property prices data. First, the database for regression analysis is used for 1 year only and from only one transaction company. Although the included broker transaction represents $70-80 \%$ of all transactions, we cannot exclude the selection effect; thus, conclusions should be drawn carefully. Second, the method involving the layering of polygons of parks on top of the apartment transaction sales polygons may have resulted in an overestimation of the effects of parks in central city areas. Third, as a result of the way crime rates were measured, it is possible that unexpected outliers or extremely high crime rates may have been produced. A related issue is that high crime rates reflect both the size of the numerator and the denominator. A problem arises if the denominator is small in size (owing to a relatively large numerator), in that it may inflate the crime rates (a small resident population may inflate rates). To produce more reliable rates for parks, future research should attempt to find better variables as denominators. The area of the polygon or the number of people who pass by/pass through the park might be some possible alternatives to using the resident population to represent the denominator. In this study, the weight matrix was defined on the basis of neighbourhood polygon structure; however, the distance matrix of the original point data seems more appropriate. Future studies should use either a given distance band that defines neighbourhood or a distance decay. Fourth, the threshold provided for the buffers $(0-50 \mathrm{~m}, 50-100 \mathrm{~m}$ and $100-150 \mathrm{~m})$ are not problem free. The location of an apartment between two parks could make it difficult to identify which park is being amortized into the apartment price. Thus, the conclusion should be drawn carefully. Fifth, when analysing individual and neighbourhood variables, a multilevel model is generally more appropriate than an ordinary single-level regression model because it enables researchers to deal with the hierarchical structure of variables (for more detail, see Park \& Kim, 2014). The multilevel model assumes that individuals (i.e. lower hierarchy) belonging to a particular neighbourhood (i.e. higher hierarchy) are not independent of each other because they are presumed to be influenced similarly by the characteristics of that neighbourhood; thus, the model considers intra-neighbourhood correlation. In future research, we intend to use the multilevel model to obtain unbiased regression results.

Future studies should expand the analysis to include different housing categories (e.g. villas) with various attributes of parks so as to enhance the understanding of potential residents' choice and willingness to pay for a property. These findings may also be applied to other cities with a similar structure to that of Stockholm, namely, with a relatively low population density and a large number of parks. On the periphery of Stockholm, other dimensions that go beyond environmental features should also be considered in future studies, such as distance to schools. In addition, future studies on crime in parks should examine different segments of the housing market (see, for instance, Wilhelmsson \& Ceccato, 2015).

Despite the limitations, this study illustrates how parks and crime relate to apartment prices when both housing and area characteristics are controlled for. The main message of 
these findings is that investing in the safety of parks not only directly affects the quality of an area but also increases property prices. However, the outcomes of this investment depend on the types of parks and the types of crime that are committed at or near the parks. These findings are important from the perspectives of three different groups of people: individual citizens searching for a new home, police and other safety experts and urban planners.

Individual citizens searching for a new home can make use of the 'crime-park argument' to obtain a discount when purchasing a property that is located near a park with a high crime rate. For police and other safety experts, findings of this type can be used to identify parks and/or areas that are in greater need of resources and targeting programmes, at least at certain times of the day. For urban planners, these findings can be helpful in two ways. From a physical planning perspective, if certain parks are highly prone to crime, the following questions about the nature of the parks and the activities within the parks need to be asked: What types of activities in parks allow crime to happen? How can these park activities be better planned to avoid these unwanted encounters? From a social perspective, findings such as those presented in this study can be used in the early detection of other problems in the area. For instance, an area with a high crime rate may also become plagued with other social problems that are expressed in parks which, in the long run, could speed up the exodus of residents. Decreasing housing prices may be an indication of the area's decay. The area may decay even more if no intervention is put in place and on time. Therefore, the quality of parks can be used as an indicator of an area's wellbeing.

\section{Acknowledgments}

This research was funded by the Swedish Research Council FORMAS [grant number 259-20121189]. Special thanks to Prof. Mats Wilhelmsson (KTH) for providing property sale's data and his valuable comments in previous versions of this article. Thanks to Stockholm County Police, Stockholm's city planning office and Mäklarstatistik for providing data for the analysis. We thank the editor and two anonymous reviewers for their constructive comments, which helped us to improve the manuscript.

\section{References}

Anselin, L. (1988). Spatial econometrics: Methods and models. Dordrecht: Kluwer Academic.

BRA. (2013). Crime statistics. Retrieved August 2, 2013, from http://www.bra.se/bra/brott-ochstatistik/statistik.html

Can, A. (1990). The measurement of neighborhood dynamics in urban house prices. Economic Geography, 66, 254-272. doi:10.2307/143400

Ceccato, V., \& Haining, R. (2005). Assessing the geography of vandalism: Evidence from a Swedish City. Urban Studies, 42, 1637-1656. doi:10.1080/00420980500185645

Ceccato, V., Haining, R., \& Signoretta, P. (2002). Exploring offence statistics in Stockholm City using spatial analysis tools. Annals of the Association of American Geographers, 92, 29-51. doi: $10.1111 / 1467-8306.00278$

Ceccato, V., \& Wilhelmsson, M. (2011). The impact of crime on apartment prices: Evidence from Stockholm, Sweden. Geografiska Annaler: Series B, Human Geography, 9, 1-23.

Chiesura, A. (2004). The role of urban parks for the sustainable city. Landscape and Urban Planning, 68, 129-138. doi:10.1016/j.landurbplan.2003.08.003

Cho, S. H., Clark, C. D, Park, W. M., \& Kim, S. G. (2009). Spatial and temporal variation in the housing market values of lot size and open space. Land Economics, 85, 51-73.

Cho, S. H., Poudyal, N. C., \& Roberts, R. K. (2008). Spatial analysis of the amenity value of green open space. Ecological Economics, 66, 403-416. doi:10.1016/j.ecolecon.2007.10.012 
Cohen, L., \& Felson, M. (1979). Social change and crime rate trends: A routine activity approach. American Sociological Review, 44, 588-608. doi:10.2307/2094589

Court, A. T. (1939). Hedonic price indexes with automotive examples. In Charles F. Roos (Ed.), The dynamics of automotive demand (pp. 99-117). New York: General Motors.

Dehring, C., \& Dunse, N. (2006). Housing density and the effect of proximity to public open space in Aberdeen, Scotland. Real Estate Economics, 34, 553-566. doi:10.1111/j.1540-6229.2006. 00178.x

Dubin, A. C., \& Goodman, R. A. (1982). Valuation of education and crime neighborhood characteristics through hedonic housing prices. Population and Environment, 5, 166-181. doi:10.1007/BF01257055

Eurostat Regional Yearbook. (2012). The Statistical Atlas: A new interactive tool. The Eurostat website Eurostat Commission-STAT/12/143, Retrieved October 11, 2012, from http://www. ec.europa.eu/regional_policy/newsroom/detail.cfm?id = 334\&LAN $=$ EN

Föbker, S., \& Grotz, R. (2006). Everyday mobility of elderly people in different urban settings: The example of the city of Bonn, Germany. Urban Studies, 43, 99-118. Retrieved from http://usj. sagepub.com/content/43/1/99.full.pdf + html

Geoghegan, J., Wainger, L., \& Bockstael, N. E. (1997). Spatial landscape indices in a hedonic framework: An ecological economics analysis using GIS. Ecological Economics, 23, 251-264. doi:10.1016/S0921-8009(97)00583-1

Goodman, A. C., \& Thibodeau, T. G. (1998). Housing market segmentation. Journal of Housing Economics, 7, 121-143. doi:10.1006/jhec.1998.0229

Groff, E., \& McCord, E. S. (2011). The role of neighborhood parks as crime generators. Security Journal, 25, 1-24. doi:10.1057/sj.2011.1

Halvorsen, R., \& Pollakowski, H. O. (1981). The effects of fuel prices on house prices. Urban Studies, 18, 205-211. doi:10.1080/00420988120080361

Herzog, T., \& Kirk, K. (2005). Pathway curvature and border visibility as predictors of preference and danger in forest settings. Environment and Behavior, 37, 620-639. doi:10.1177/ 0013916505275306

Hilborn, J. (2009). Dealing with crime and disorder in urban parks. Problem-Oriented Guides for Police Response Guides Series, 9, 1-63. Retrieved from http://www.cops.usdoj.gov

Iqbal, A. (2012). Property values, parks and crime: A hedonic analysis in Stockholm, Sweden. (Master's thesis KTH). Retrieved March 20, 2013, from http://www.diva-portal.org/smash/ record.jsf?pid $=$ diva2\%3A538544\&dswid $=634$

Jim, C. Y., \& Chen, W. Y. (2010). External effects of neighbourhood parks and landscape elements on high-rise residential value. Land Use Policy, 27, 662-670. doi:10.1016/j.landusepol.2009.08. 027

Karlsson, V. (2008). The relationship between housing prices and transport improvements: A comparison of metropolitan and rural areas in a large but thinly populated European country. Bifröst Journal of Social Science, 2, 141-166.

Kestens, Y., Thériault, M., \& Rosiers, F. D. (2004). The impact of surrounding land use and vegetation on single-family house prices. Environment and Planning B: Planning and Design, 31, 539-567. doi:10.1068/b3023

Kiel, A. K., \& Zabel, E. J. (2008). Location, location, location: The 3L approach to house price determination. Journal of Housing Economics, 17, 175-190. doi:10.1016/j.jhe.2007. 12.002

Knutsson, J. (1997). Restoring public order in a city park. National Council for Crime Prevention, Sweden, 133-151. Retrieved August 1, 2011, from http://www.popcenter.org/library/ CrimePrevention/Volume_07/05_knuttson.pdf

Kong, F., Yin, H., \& Nakagoshi, N. (2007). Using GIS and landscape metrics in the hedonic price modeling of the amenity value of urban green space: A case study in Jinan City, China. Landscape and Urban Planning, 79, 240-252. doi:10.1016/j.landurbplan.2006.02.013

Kryvobokov, M., \& Wilhelmsson, M. (2007). Analysing location attributes with a hedonic model for apartment prices in Donetsk Ukraine. International Journal of Strategic Property Management, $11,157-178$.

Kuo, F. E., \& Sullivan, W. E. (2001). Environment and crime in the inner city: Does vegetation reduce crime? Environment and Behaviour, 33, 343-367. doi:10.1177/00139160121973025

Larsen, J. E., Lowrey, K. J., \& Coleman, J. W. (2003). The effect of proximity to a registered sex offender's residence on single-family house selling price. Appraisal Journal, 71, 253-265. 
Linden, L., \& Rockoff, J. (2008). Estimates of the impact of crime risk on property values from Megan's laws. American Economic Review, 98, 1103-1127. doi:10.1257/aer.98.3.1103

Luttik, J. (2000). The value of trees, water and open space as reflected by house prices in the Netherlands. Landscape and Urban Planning, 48, 161-167. doi:10.1016/S0169-2046(00) 00039-6

McCormack, G. A., Rock, M., Toohey, A. M., \& Hignell, D. (2010). Characteristics of urban parks associated with park use and physical activity: A review of qualitative research. Health \& Place, 16, 712-726. doi:10.1016/j.healthplace.2010.03.003

Michael, S., Hull, R., \& Zahm, D. (2001). Environmental factors influencing auto burglary: A case study. Environment and Behaviour, 33, 368-388. doi:10.1177/00139160121973034

Mitchell, D. (1995). The end of public space? People's park, definition of public, and democracy. Annals of the Association of American Geographers, 85, 108-133.

Morancho, A. B. (2003). A hedonic valuation of urban green areas. Landscape and Urban Planning, 66, 35-41. doi:10.1016/S0169-2046(03)00093-8

More, T. A., Stevens, T., \& Allen, P. G. (1988). Valuation of urban parks. Landscape and Urban Planning, 15, 139-152. doi:10.1016/0169-2046(88)90022-9

Munroe, D. (2007). Exploring the determinants of spatial pattern in residential land markets: Amenities and disamenities in Charlotte, NC, USA. Environment and Planning B: Planning and Design, 34, 336-354. doi:10.1068/b32065

Orford, S. (2002). Valuing locational externalities: A GIS and multilevel modelling approach. Environment and Planning B: Planning and Design, 29, 105-127. doi:10.1068/b2780

Park, Y. M., \& Kim, Y. (2014). A spatially filtered multilevel model to account for spatial dependency: Application to self-rated health status in South Korea. International Journal of Health Geography, 13, 6. doi:10.1186/1476-072X-13-6

Piza, E. L., \& Kennedy, D. (2003). Transit stops, robbery, and routine activities: Examining street robbery in the Newark. NJ Subway Environment. Retrieved from http://proceedings.esri.com/ library/userconf/proc04/docs/pap1303.pdf

Rosen, S. (1974). Hedonic prices and implicit markets: Product differentiation in pure competition. Journal of Political Economy, 82, 34-55. doi:10.1086/260169

Sampson, R. J., \& Raudenbush, S. W. (1999). Systematic social observation of public spaces: A new look at disorder in urban neighborhoods. American Journal of Sociology, 105, 603-651. doi:10. $1086 / 210356$

Statistiska centralbyrån. (2013). Statistiska Centralbyrån (Statistics Sweden yearly report). Retrieved June 10, 2013, from http://www.scb.se/statistik/_publikationer/OV0904_2013A01_BR_00_ A01BR1301.pdf

Shultz, S., \& King, D. (2001). The use of census data for hedonic price estimates of open space amenities and land use. Journal of Real Estate Finance and Economics, 22, 239-252. doi:10. 1023/A:1007895631071

Song, H. S., \& Wilhelmsson, M. (2010). Improved price index for condominiums. Journal of Property Research, 27, 39-60. doi:10.1080/09599916.2010.500394

Ståhle, A. (2006). Sociotope mapping-Exploring public open space and its multiple use values in urban and landscape planning practice. Nordic Journal of Architectural Research, 19, $59-71$.

Stockholms stad. (2006). Stockholms parkprogram-Stockholm: Kommunfullmäktige (City of Stockholm, Stockholm park programs-Stockholm: City Council). Retrieved June 10, 2011, from http://www.spacescape.se/pdf/StockholmsParkprogram2006.pdf

Stockholms stad. (2009). Stockholms översiktsplan-Stockholm: Kommunfullmäktige (City of Stockholm, Stockholm's master plan - Stockholm: City Council) Council. Retrieved June 10, 2011, from www.international.stockholm.se/Politics-and-organisation/Annual-reports/

Stockholms stad. (2012). Kommunfullmäktige, City of Stockholm: The City Council. Retrieved December 1, 2012, from www.international.stockholm.se/-/News-from-the-City-of-Stockholm/ News/Stockholm-topsglobal-list-of-most-attractive-cities/

Troy, A., \& Grove, J. M. (2008). Property values, parks, and crime: A hedonic analysis in Baltimore, MD. Landscape and Urban Planning, 87, 233-245. doi:10.1016/j.landurbplan.2008.06.005

Tyrväinen, L., \& Mäkinen, K. (2004). Tools for mapping social values and meanings of urban woodlands and other open space. OPEN SPACE: PEOPLE SPACE. An International Conference on Inclusive Outdoor Environments. 27th - 29th October 2004, Edinburgh, UK. 
Tyrväinen, L., \& Väänänen, H. (1998). The economic value of urban forest amenities: An application of the contingent valuation method. Landscape and Urban Planning, 43, 105-118.

USKAB. (2013). Stadsdelsinvånarna om miljö och miljövanor i Stockholm 2004: Medborgarenkät 2004. Stockholm: Miljöförvaltningen. [Neighbourhood residents about the environment and environmental habits in Stockholm: Citizens' Survey 2004, Stockholm: The Environment Department].

Wilhelmsson, M., \& Ceccato, V. (2015) Does burglary affect property prices in a non-metropolitan municipality? Journal of Rural Studies (in press).

Wikström, P. H. (1991). Urban crime, criminals, and victims: The Swedish experience in an AngloAmerican comparative perspective. Stockholm: Springer-Verlag.

Wilson, J. Q., \& Kelling, G. L. (1982). Broken windows: The police and neighborhood safety. The Atlantic Monthly. Retrieved September 20, 2011, from http://www.manhattaninstitute.org/pdf/_ atlantic_monthly-broken_windows.pdf 


\section{Appendix 1}

Types of parks and green spaces.

\begin{tabular}{lcccl}
\hline Green space type & $\begin{array}{c}\text { Min. size } \\
\text { (ha) }\end{array}$ & $\begin{array}{c}\text { Availability } \\
\text { within }(\mathrm{m})\end{array}$ & $\begin{array}{c}\text { Number of } \\
\text { parks }\end{array}$ & Specifications \\
\hline $\begin{array}{l}\text { Local parks } \\
\text { City district parks }\end{array}$ & $\begin{array}{l}0.5-5 \\
5-50\end{array}$ & $<200$ & 446 & $\begin{array}{l}\text { SYs, PGs, park blocks, NPs } \\
\text { ICPs, SPs, CMs, HPs, BPs, }\end{array}$ \\
& & & 568 & $\begin{array}{l}\text { PPs, CGPs, landscape parks, } \\
\text { sports arena, esplanade, } \\
\text { grass parks }\end{array}$ \\
$\begin{array}{l}\text { Nature and recreation } \\
\text { areas }\end{array}$ & & & & LNPs and forests \\
\hline
\end{tabular}

Source: Stockholm Park Programme by Stockholm City Council (2006). 
Appendix 2

Definitions of variables.

\begin{tabular}{|c|c|c|c|c|}
\hline Variable & Description & Unit & Average & $\begin{array}{l}\text { Standard } \\
\text { deviation }\end{array}$ \\
\hline \multicolumn{5}{|c|}{ Variables from Mäklarstatistik } \\
\hline Price & Transaction price & SEK & 14.52 & 0.52 \\
\hline Area & Living area & Square metre & 4.04 & 0.42 \\
\hline Room & No. of room & Number & 0.74 & 0.45 \\
\hline Fee & Monthly fee & SEK & 7.91 & 0.56 \\
\hline Age1 & Before 1900 & Binary & 0.05 & 0.22 \\
\hline Age2 & $1900-1930$ & Binary & 0.35 & 0.47 \\
\hline Age3 & $1930-1945$ & Binary & 0.22 & 0.41 \\
\hline Age4 & $1945-1965$ & Binary & 0.08 & 0.27 \\
\hline Age 5 & $1965-1993$ & Binary & 0.06 & 0.24 \\
\hline New & Sale year $=$ building year & Binary & 0.01 & 0.11 \\
\hline Elevator & $\begin{array}{l}\text { Elevator in the } \\
\text { house }\end{array}$ & Binary & 0.58 & 0.49 \\
\hline Balcony & $\begin{array}{l}\text { Balcony in the } \\
\text { apartment }\end{array}$ & Binary & 0.10 & 0.30 \\
\hline First & First floor & Binary & 0.20 & 0.40 \\
\hline Top & Top floor & Binary & 0.26 & 0.44 \\
\hline \multicolumn{5}{|c|}{$\begin{array}{l}\text { Variables from Stockholm } \\
\text { city planning office }\end{array}$} \\
\hline Water 100 & $100 \mathrm{~m}$ buffer from water & Binary & 0.08 & 0.27 \\
\hline Water300 & $300 \mathrm{~m}$ buffer from water & Binary & 0.30 & 0.46 \\
\hline Water500 & $500 \mathrm{~m}$ buffer from water & Binary & 0.48 & 0.49 \\
\hline Sub100 & $\begin{array}{l}100 \mathrm{~m} \text { buffer from subway } \\
\text { station }\end{array}$ & Binary & 0.10 & 0.30 \\
\hline Sub300 & $\begin{array}{l}300 \text { m buffer from subway } \\
\text { station }\end{array}$ & Binary & 0.46 & 0.49 \\
\hline Sub500 & $\begin{array}{l}500 \mathrm{~m} \text { buffer from subway } \\
\text { station }\end{array}$ & Binary & 0.70 & 0.45 \\
\hline Train 100 & $\begin{array}{l}100 \mathrm{~m} \text { buffer from commuting } \\
\text { train station }\end{array}$ & Binary & 0.00 & 0.09 \\
\hline Train300 & $\begin{array}{l}300 \mathrm{~m} \text { buffer from commuting } \\
\text { train station }\end{array}$ & Binary & 0.03 & 0.19 \\
\hline Train500 & $\begin{array}{l}500 \mathrm{~m} \text { buffer from commuting } \\
\text { train station }\end{array}$ & Binary & 0.08 & 0.28 \\
\hline Road100 & 100 m buffer from highway & Binary & 0.00 & 0.08 \\
\hline Road300 & $300 \mathrm{~m}$ buffer from highway & Binary & 0.06 & 0.24 \\
\hline Road500 & $500 \mathrm{~m}$ buffer from highway & Binary & 0.15 & 0.36 \\
\hline Main100 & $\begin{array}{l}100 \text { m buffer from main } \\
\text { street }\end{array}$ & Binary & 0.26 & 0.44 \\
\hline Main300 & $\begin{array}{l}300 \mathrm{~m} \text { buffer from main } \\
\text { street }\end{array}$ & Binary & 0.64 & 0.47 \\
\hline Main500 & $\begin{array}{l}500 \mathrm{~m} \text { buffer from main } \\
\text { street }\end{array}$ & Binary & 0.80 & 0.39 \\
\hline Distance & $\begin{array}{l}\text { Distance to city } \\
\text { centre }\end{array}$ & Metres & 8.30 & 0.69 \\
\hline
\end{tabular}


- continued

\begin{tabular}{|c|c|c|c|c|}
\hline Variable & Description & Unit & Average & $\begin{array}{l}\text { Standard } \\
\text { deviation }\end{array}$ \\
\hline \multicolumn{5}{|c|}{ Variables from Stockholm County Police } \\
\hline Crime & $\begin{array}{l}\text { Crime rate per } \\
10,000 \text { inhabitants }\end{array}$ & Ratio & 7.21 & .75 \\
\hline Robbery & $\begin{array}{l}\text { Robbery per } 10,000 \\
\text { inhabitants }\end{array}$ & Ratio & 2.10 & 1.22 \\
\hline Vandalism & $\begin{array}{l}\text { Vandalism per square } \\
\text { metre of area }\end{array}$ & Ratio & .92 & 1.07 \\
\hline Violence & $\begin{array}{l}\text { Outdoor violence per } \\
10,000 \text { inhabitants }\end{array}$ & Ratio & 3.25 & 1.30 \\
\hline Burglary & $\begin{array}{l}\text { Residential burglary per } \\
10,000 \text { inhabitants }\end{array}$ & Ratio & 3.66 & 0.85 \\
\hline Theft & $\begin{array}{l}\text { Theft per square } \\
\text { metre of area }\end{array}$ & Ratio & 1.67 & 0.99 \\
\hline \multicolumn{5}{|c|}{ Park variables from Stockholm city planning office } \\
\hline Aggregated park* & $\begin{array}{l}\text { Park as an } \\
\text { aggregated measure } \\
(1 / 0=\text { having or not } \\
\text { having a park })\end{array}$ & Binary & 0.11 & 0.32 \\
\hline
\end{tabular}




\section{Journal of Scandinavian Studies in Criminology and Crime Prevention}

\section{Does crime in parks affect apartment prices?}

\section{Asifa Iqbal \& Vania Ceccato}

To cite this article: Asifa Iqbal \& Vania Ceccato (2015) Does crime in parks affect apartment prices?, Journal of Scandinavian Studies in Criminology and Crime Prevention, 16:1, 97-121, DOI: $10.1080 / 14043858.2015 .1009674$

To link to this article: http://dx.doi.org/10.1080/14043858.2015.1009674

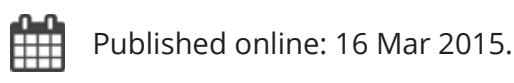

Submit your article to this journal ¿

LIII Article views: 96

Q View related articles $\sqsubset$

View Crossmark data $\nearrow$ 